\title{
MUNKA VS. MAGÁNÉLET - LÉTEZIK-E EGYENSÚLY?
}

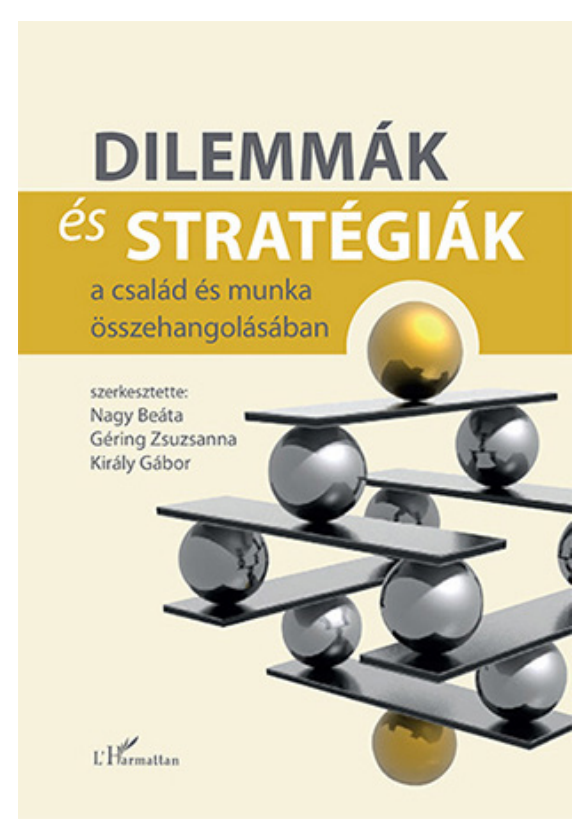

Nagy B. - Géring Zs. - Király G. (szerk.)

Dilemmák és stratégiák a család és munka összehangolásában L'Harmattan Kiadó, Budapest

DOI: 10.18030/socio.hu.2019.1.108

A 2018-ban megjelent kötet hiánypótlónak tekinthető a hazai társadalomtudományi szakirodalomban, mivel ezidáig nem jelent meg a munka és magánélet összehangolását vizsgáló magyar nyelvű kötet, miközben köztudott, hogy Magyarországon a háztartási munkamegosztás és a gyermekneveléssel kapcsolatos feladatok egyenlőtlenül oszlanak meg a férfiak és a nők között (lásd például Pongráczné-Murinkó 2009, Takács 2008). Sőt az attitűdök szintjén is az a jellemző, hogy a kenyérkereső munkát elsősorban a férfiaktól, míg a gondozási feladatokat elsősorban a nőktől várják el Magyarországon (Gergor 2016, Murinkó 2014, Szalma 2010).

A kötet négy részre tagolódik: Elméleti írások, Módszertani irások, Társadalom és szervezet, valamit Egyéni dilemmák. Az Elméleti írások fejezettől azt kapja az olvasó, amit egy ilyen jellegű fejezettől várni lehet: a már létező irodalom áttekintését. Az első rész tanulmányai egy adott téma köré csoportosítva mutatják be a nők és férfiak közötti egyenlőtlenségeket a (fizetett) munka és a család (nem fizetett munka) kontextusában, kisebbnagyobb átfedésekkel.

Nagy Beáta, Géring Zsuzsanna és Király Gábor tanulmánya a posztszocialista országokra fókuszál, ahol még mindig csak hiú ábránd a nők és férfiak egyenjogúságának gyakorlati megvalósulása. A második írás szerzői (Király Gábor, Nagy Beáta, Géring Zsuzsanna, Radó Márta, Lovas Yvette és Pálóczi Bence) a spillover² jelenséggel kapcsolatos szakirodalmi áttekintésben rávilágítanak arra, hogy miért lenne fontos, hogy a kelet-közép-európai országok is felkerüljenek a munka és a magánélet kutatásának térképére: az eddig megjelent szakirodalom

1 Szalma Ivett tudományos munkatárs, MTA TK Szociológiai Intézet, Budapesti Corvinus Egyetem. Vida Anna és Vizkeleti Fruzsina a Budapesti Corvinus Egyetem közgazdálkodás és közpolitika mesterszakos hallgatói.

2 Ez a jelenség arra utal, hogy a munkahely és a magánélet szférái között nincsenek éles határvonalak. Az egyik területen tapasztalt pozitív vagy negatív érzelmek, attitűdök, értékek, képességek és viselkedések átszűrődhetnek más életszférákra is. 
többsége ugyanis főleg az angolszász kultúrkörre és azon belül is meghatározott célcsoportokra vonatkozott: például heteroszexuális párkapcsolatban együtt élőkre, ahol mindkét fél munkát vállal. A szakirodalmi áttekintés fontos korlátja, hogy a szerzők csak angol nyelvű publikációkat vizsgáltak, így eredményeikben az angolszász túlsúly nyilván ennek is köszönhető. A harmadik tanulmány Paksi Veronika írása, aki arra a kérdésre keresi a választ, hogy miért kevés a női hallgató a természet- és műszaki tudományi képzésekben. A tanulmányból kiderül, hogy e mögött olyan strukturális tényezők húzódnak meg, mint például a tudományterülethez hozzákapcsolódott maszkulin világkép vagy a nők pályaválasztását befolyásoló hagyományos nemi szerepek és sztereotípiák. Ezt követően Geszler Nikolett két írása zárja az első részt. A munka és a család konfliktusának forrásai az európai férfiak életében címú írás több ponton mutat átfedést a spilloverről szóló fejezettel, ám Geszler írásai kifejezetten a férfiak szemszögéből közelítik a témát. Második tanulmányában a skandináv államokra fókuszál és jó gyakorlatként hivatkozik rájuk, mivel ezekben a társadalmakban az állam különböző engedményekkel sarkallja a férfiakat a törődő apaszerep vállalására a családi életben.

A módszertani írások rész három tanulmányt foglal magában. Az elsőben Király Gábor, Dén-Nagy Ildikó, Géring Zsuzsanna és Nagy Beáta egy paradigmaváltásra hívja fel a figyelmet: míg a korábbi kutatások egy zárt módszertani struktúrában mozogtak abban az értelemben, hogy vagy kvalitatív vagy kvantitatív módszert használtak, időközben egyre inkább fontossá vált a kevert módszerek alkalmazása is. A következő tanulmányban Dén-Nagy Ildikó és szerzőtársai folytatják a kevert módszertanok bemutatását, ezúttal kifejezetten azzal a céllal, hogy rávilágítsanak, miként lehet a munka-magánélet egyensúly kutatásában ezt a megközelítést a gyakorlatba is átültetni. A harmadik tanulmányban Géring Zsuzsanna a tartalomelemzés módszerét ismerteti, ami azért is érdekes, mert a tartalomelemzés önmagában a kvalitatív és kvantitatív módszerek határán áll, kapcsolódva így a kevert módszerek témaköréhez.

A kötet harmadik része a Társadalom és szervezet alcímet viseli, és hat tanulmányt foglal magában. Az elsőben Radó Márta, Nagy Beáta és Király Gábor a kötet korábbi tanulmányaiban már jól körbejárt munka-család spillover hatásokat elemzi ezúttal gender megközelítésből. Fontos eredményeik közé tartozik, hogy a spillover jelensége a nemek közötti egyenlőtlenségek új dimenzióját is képviselheti az egyenlőtlenségek hagyományos formái mellett. Továbbá arra is fény derül, hogy az angolszász társadalmakkal szemben Magyarországon fontosabb szerepe lehet az anyagi jólétnek a spillover hatások érvényesülésében. A tanulmány kétségtelenül úttörő jellegú abból a szempontból, hogy a spillover hatásokat Magyarországra vonatkozóan elemzi, ugyanakkor a szerzők túlzott általánosítással élnek, amikor az eredményeiket érvényesnek aposztrofálják az egész kelet-közép-európai kontextusra is.

Rési Kata Ildikó írása a crossover hatásokra fókuszál a European Social Survey nemzetközi adatbázis 5. hullámának adatait felhasználva. Míg a korábban már tárgyalt spillover esetén egyazon egyén érzései szivárognak át a család és a munka között, addig a crossover esetén az egyik fél által tapasztalt érzések a partnerben vagy más hozzá közel álló személyben hasonló érzéseket (pl. stresszt, feszültséget) válthatnak ki. A tanulmány egyik korlátja, hogy az olvasó számára nem világos, hogy pontosan mely országok kerültek be az elemzésbe, továbbá az országcsoportok közötti lehetséges eltérések vizsgálata teljesen kimaradt az elemzésből. 
A következő négy tanulmány fókusza a vállalati felelősségvállalás. Géring Zsuzsanna tartalomelemzéssel azt vizsgálja, hogy a 150 főnél több munkavállalót alkalmazó vállalatok honlapján megjelenik-e a munka és a magánélet egyensúlyára vonatkozó kommunikáció. A válasz sajnos nemleges, viszont reményre adhat okot, hogy a külföldi nagyvállalatok sokszor az anyacégektől átvett normák és struktúrák szerint megjelenítik a munkavállalókkal kapcsolatos információkat a honlapjukon, azaz ezek a vállalatok a hazai gazdasági élet szereplőiként a munka és magánélet egyensúlyára törekvés elvének a terjesztőivé válhatnak. A szerző arra is kitér, hogy érdemes lenne hasonló jellegű elemzést végezni a kisvállatok körében, hiszen létszám szerint a kisméretű vállalatok alkotják a hazai vállalatok jelentős hányadát.

Geszler Nikolett írásának empirikus alapja 43 menedzserpozícióban lévő apával készített interjú. A kutatás eredményei rávilágítanak arra, hogy eléggé korlátozott mozgástere van a menedzserapáknak a munka és a család közötti egyensúly megteremtésére: interjúalanyai közül például senki sem élt a szülői szabadság vagy a részmunkaidő lehetőségeivel. Ugyanakkor az otthoni munkavégzés és a rugalmas munkaidő igénybevételén keresztül legalább részben ki tudják elégíteni a családi életben való részvételre vonatkozó törekvéseiket. Oborni Katalin esettanulmányában szintén a nagyvállalatok világát helyezi a fókuszba, amikor azt vizsgálja, hogy ezek a szervezetek milyen megoldásokat kínálnak a munka és a magánélet összeegyeztethetőségére.

A harmadik rész utolsó és talán legizgalmasabb tanulmányában Koplányi Emese a mai magyar társadalom egyik igen aktuális problémájára fókuszál: a munkapiacon dolgozó anyákat érintő hátrányokra. Ehhez az Egyenlő Bánásmód Hatóság (EBH) 2005 és 2013 közötti anyasági és apasági diszkriminációval foglalkozó 43 határozatát elemzi kvalitatív módszerrel. A kutatás legfőbb eredménye, hogy a puha szankciók nem vezetnek eredményre, hiszen sokszor újabb hátrányos megkülönböztetés érte az anyákat ugyanannál a szervezetnél. A szerző fontos közpolitikai javaslatokat is tesz például egy állami szintű esélyegyenlőségi program létrehozására, valamint arra, hogy egy-egy bejelentett eset után kötelező legyen az EBH-nak visszatérő ellenőrzést végeznie, hogy biztosan ne alkalmazzanak újra diszkriminációt az anyákkal szemben ugyannál a cégnél a későbbiekben sem.

A kötet negyedik, egyben leginnovatívabb része az egyéni dilemmákat tárgyalja hat kiváló tanulmányban. Dén-Nagy Ildikó írása feltárja a mobiltechnológia használata és a munka-magánélet egyensúly megteremtése közötti sokrétű kapcsolatot, továbbá bemutatja, hogy az emberek hogyan értelmezik a mobiltelefon szerepét a munka, a magánélet és a kettő összeegyeztetése területén. A kutatás fő célkitűzése az volt, hogy megválaszolja az alábbi kérdést: Milyen hatással van a mobiltelefon-használat az érzékelt spilloverre? A kutatás rávilágított arra, hogy a különböző társadalmi csoportok eltérően értelmezhetik a technológiai vívmányok szerepét a munka-magánélet egyensúlyának megteremtésében.

Ezt követően Neményi Mária és Takács Judit egy rendhagyó társadalmi jelenséget mutat be: a családfenntartó anyák munka-magánélet harmonizációs kísérleteit vizsgálja Magyarországon. A kutatás fő kérdése, hogy a társukhoz képest magasabb jövedelemmel rendelkező anyák képesek-e megküzdeni azokkal a nehézségekkel, amelyek e rendhagyó helyzetben felmerülhetnek. A kutatásban négy, elméletileg lehetséges családmodellt állítottak fel. Az első a tradicionális modell, melyben a nő jövedelme magasabb, de a férfi „tekintélye alá rendeli magát”, így a társadalmilag elvárt szerepfelfogás valósul meg. Az egalitariánus modellt nem alá-fölérendeltségi viszony jellemzi: ez egy egyenrangú kapcsolat, mely kölcsönös alkalmazkodásra épül. A harmadik 
a kényszer szülte fordított modell, mely során a családok a hagyományos modellt preferálnák, de időközben olyan változás következett be életükbe, ami a nőt belekényszeríti a családfenntartó szerepbe. A negyedik csoportot az öntudatosan felvállalt fordított szerep jellemezte, ami együtt járt az atipikus női szerepviselkedéssel. E helyzetekben, ahol a társadalmi elvárást felülírja a domináns személyiség ereje, az ambiciózus nők határozzák meg a párkapcsolat és a családi együttmúködés jellegét.

A következő tanulmányban Kiss Zsófia Viktória egy eddig kevéssé vizsgált foglalkoztatási csoportra, a fuvarozási ágazatban dolgozó tehergépjármű-vezetőkre fókuszál. A kutatás a következő három fő téma köré épült: az interjúalanyok hogyan értékelték a munkájuk és magánéletük közötti kapcsolatot, valamint a vállalatokat olyan szempontból, hogy milyen lépéseket tettek a dolgozók jóllétéért, kiegyensúlyozottságáért. Végül az interjúalanyok beszámoltak arról, hogy mennyire voltak képesek befolyásolni időbeosztásukat, illetve mennyire éreztek kontrollt.

Hirsch Johanna fókuszcsoportos vizsgálatában azt elemezte, hogy megfigyelhetők-e nemspecifikus különbségek orvostanhallgatók karrierterveiben Magyarországon. A fókuszcsoportos vizsgálat rávilágít arra, hogy a női hallgatók már a pályaválasztás pillanatában is nagy hangsúlyt fektetnek a gyermekvállalás kérdéskörére és a munka-magánélet összeegyeztetésének problémájára. Az orvosi szakmában megjelenő nemi szegregációt az orvostanhallgatók maguk is érzékelik. A kutatás során az orvosi migráció kérdése is felmerült, melynek lehetősége elől egyetlen megkérdezett hallgató sem zárkózott el.

Paksi Veronika, Nagy Beáta és Király Gábor tanulmánya némileg kapcsolódik az előzőhöz: a legmagasabb oktatási szinten vizsgálja, hogy a mérnöki PhD-tanulmányokat folytató nők miként tudják összehangolni az anyaságot a tanulói és munkavállalói státusszal. Az írás rávilágít arra, hogy a mérnöknők már a PhD-képzés alatt komoly dilemmákkal szembesülnek a munka-magánélet egyensúlya kapcsán, amire alig találnak jó megoldásokat. Az egyik legnagyobb kihívást a gyermekvállalás időzítése jelenti, amit a különböző strukturális tényezők, normatív hatások és a labormunka során használt vegyszerek használata jelentősen befolyásol.

Végül a Ki áll a sikeres nő mögött? címú zárófejezetben Nagy Beáta a magas beosztású női vezetők körében vizsgálta a munka-magánélet egyensúly különösen kényes kérdéskörét, mivel kettős teher hárul rájuk. A kutatás a következő támogatási formákat azonosította: érzelmi támogatás, háztartási segítség, a családtagok körüli segítés, karriertámogatás és munkahelyi megbecsülés. Kiemelkedő szerepe van a partnertámogatásnak, ami érzelmi és társas támogatásban, mint például a gondoskodás és elfogadás, manifesztálódik.

A kötet minden hazai társadalomtudomány iránt érdeklődőnek ajánlható, hiszen a munka-magánélet kutatásról nyújt nemzetközi kitekintést, miközben számos hazai problémára is rávilágít izgalmas kutatásokon keresztül. Ugyanakkor a kötetből egy lényeges téma kimaradt: hogyan érintette a gazdasági válság a munka és a magánélet összehangolását. Miközben számos kutatás rávilágított arra, hogy a 2008-ban kezdődő gazdasági válságnak számos negatív hozadéka volt a munka-magánélet összehangolására is (lásd például: Ochsner-Szalma 2017). Ennek hiánya azért is szembeötlő, mert számos hazai kutató (többek között a kötet szerzői is) foglalkoztak ezzel a kérdéssel (lásd például: Nagy-Fodor 2015, Szalma-Takács 2013). A kötet egyik nagy erőssége, hogy egy networköt kovácsolt azáltal, hogy különböző kutatókat hozott össze: senior kutatók, doktoranduszok és mesterszakos hallgatók írásai egyaránt helyet kaptak a kötetben. 


\section{HIVATKOZÁSOK}

Gregor A. (2016) A nemi szerepekkel kapcsolatos attitűdök a 2000-es években Magyarországon. Socio.hu Társadalomtudományi Szemle, 6(1), 89-111.

Murinkó L. (2014) A nemi szerepekkel és a családdal kapcsolatos attitűdök európai kitekintésben: értékek és gyermekgondozás. Szociológiai Szemle, 24(1), 67-101.

Nagy B. - Fodor É. (2015) A gazdasági válság hatásai a férfiak és a nők munkaerő-piaci helyzetére Kelet-Közép-Európában. Szociológiai Szemle, 25(3), 2-22.

Ochsner, M. - Szalma, I. (2017) Work-life conflict of working couples before and during the crisis in 18 European countries. In Breen, M. J. (ed.) Values and identities in Europe. Evidence from the European Social Survey. Abingdon: Routledge, 77-100.

Pongrácz T. - Murinkó L. (2009) Háztartási munkamegosztás. Azonosságok és különbségek Európában. In Nagy I. - Pongrácz T. (szerk.) Szerepváltozások 2009. Jelentés a nők és férfiak helyzetéről. Budapest: TÁRKI, Szociális és Munkaügyi Minisztérium, 95-116.

Szalma I. (2010) Attitűdök a házasságról és a gyermekvállalásról. Demográfia, 53(1), 38-67.

Szalma I. - Takács J. (2013) Should men have more rights...? Gender role-related attitudes before and during the 2008 crisis. In Jónsson, G. - Stefánsson, K. (eds.) Retrenchment and Renewal? Welfare States in Times of Economic Crises - NordWel Studies in Historical Welfare State Research 6. Helsinki: Nordic Centre of Excellence Nordwell, 207-233.

Takács J. (2008) „Ha mosogatógép nem lenne, már elváltunk volna...” - Férfiak és nők otthoni munkamegosztása európai összehasonlításban. Esély, 6, 51-73. 